\title{
Observations of interannual and spatial variability in rift propagation in the Amery Ice Shelf, Antarctica, 2002-14
}

\author{
Catherine C. WALKER, ${ }^{1}$ Jeremy N. BASSIS, ${ }^{2}$ Helen A. FRICKER, ${ }^{3}$ Robin J. CZERWINSKI ${ }^{2}$ \\ ${ }^{1}$ School of Earth and Atmospheric Sciences, Georgia Institute of Technology, Atlanta, GA, USA \\ ${ }^{2}$ Atmospheric, Oceanic and Space Sciences, University of Michigan, Ann Arbor, MI, USA \\ ${ }^{3}$ Institute of Geophysics and Planetary Physics, Scripps Institution of Oceanography, University of California, San Diego, \\ La Jolla, CA, USA \\ Correspondence: Catherine C. Walker <cat.walker@eas.gatech.edu>
}

\begin{abstract}
Iceberg calving and basal melting are the two primary mass loss processes from the Antarctic ice sheet, accounting for approximately equal amounts of mass loss. Basal melting under ice shelves has been increasingly well constrained in recent work, but changes in iceberg calving rates remain poorly quantified. Here we examine the processes that precede iceberg calving, and focus on initiation and propagation of ice-shelf rifts. Using satellite imagery from the Moderate Resolution Imaging Spectroradiometer (MODIS) and the Multi-angle Imaging Spectroradiometer (MISR), we monitored five active rifts on the Amery Ice Shelf, Antarctica, from 2002 to 2014. We found a strong seasonal component: propagation rates were highest during (austral) summer and nearly zero during winter. We found substantial variability in summer propagation rates, but found no evidence that the variability was correlated with large-scale environmental drivers, such as atmospheric temperature, winds or sea-ice concentration. We did find a positive correlation between large propagation events and the arrival of tsunamis in the region. The variability appears to be related to visible structural boundaries within the ice shelf, e.g. suture zones or crevasse fields. This suggests that a complete understanding of rift propagation and iceberg calving needs to consider local heterogeneities within an ice shelf.
\end{abstract}

KEYWORDS: Antarctic glaciology, ice shelves, iceberg calving

\section{INTRODUCTION}

Mass loss from the Antarctic ice sheet takes place at its ice shelves. The two main processes that dominate this mass loss are basal melting and iceberg calving (e.g. Rignot and others, 2013). Averaged over the entire ice sheet, these two processes account for roughly equal proportions of the mass loss, but between the individual ice shelves the relative proportions vary greatly (Rignot and others, 2013). In the three largest ice shelves (Ross, Filchner-Ronne and Amery) calving accounts for as much as two-thirds of the mass loss (Rignot and others, 2013). However, because iceberg calving events can remove large amounts of mass from the ice shelf nearly instantaneously, even small changes in calving frequency or style can have a dramatic effect on the mass budget.

Iceberg calving from ice shelves is the end result of the initiation and propagation of rifts, fractures that penetrate the entire ice thickness. Many of Antarctica's ice shelves experience large calving events, in which significant sections break off from the ice front as tabular icebergs, usually following several years of propagation of a rift in the ice shelf (e.g. Jacobs and others, 1986; Lazzara and others, 1999). The availability of suitable satellite imagery since 1966 allows the process of rift propagation and how it varies over increasingly long periods to be monitored. However, the satellite observational record is still short compared with the decadal or longer recurrence interval between major tabular calving events from large ice shelves. Consequently, studies of the ice-shelf calving process have focused on understanding the factors that control the initiation and propagation of rifts, through penetrating fractures that eventually become the detachment boundary of icebergs (e.g. Larour and others, 2004; Fricker and others, 2005; Bassis and others, 2007,
2008; Benn and others, 2007; Hulbe and others, 2010; MacGregor and others, 2012; Heeszel and others, 2014).

Previous observations of Amery Ice Shelf rift propagation (Fricker and others, 2005) used satellite imagery to create an 8 year time series (1996-2004) of two rifts near the calving front. These data suggested a seasonal trend in propagation rate, where rifts propagated faster in austral summer than in austral winter. Subsequent field studies supported this finding and concluded that rift propagation did not appear to be triggered by environmental stresses, such as temperature, wind or ocean swell, although environmental factors might become more important as an iceberg becomes closer to detachment (Bassis and others, 2008). A similar conclusion was reached based on modeling studies of rifts on the Filchner-Ronne, Ross and Fimbul ice shelves (Larour and others, 2004; Joughin and MacAyeal, 2005; Humbert and Steinhage, 2011). These conclusions have been modified by studies that have argued that ocean stresses, including strong pulses of storm-induced swell, infra-gravity waves and the impact of tsunamis, might drive rift propagation (MacAyeal and others, 2006, 2009; Bromirski and others, 2010; Sergienko, 2010; Brunt and others, 2011).

A recent Antarctic-wide decade-long (2002-12) survey of rift propagation found no significant correlation between environmental triggers and rift propagation around the continent; however, that study did suggest that frontinitiated ice-shelf rifts were prone to propagation following the impact of tsunami waves (Walker and others, 2013). Of the 78 rifts observed on 13 different ice shelves, only seven actively propagated over the entire observational period; five of these were in the Amery Ice Shelf. Here we examine these five rifts in more detail, expanding on the study by 


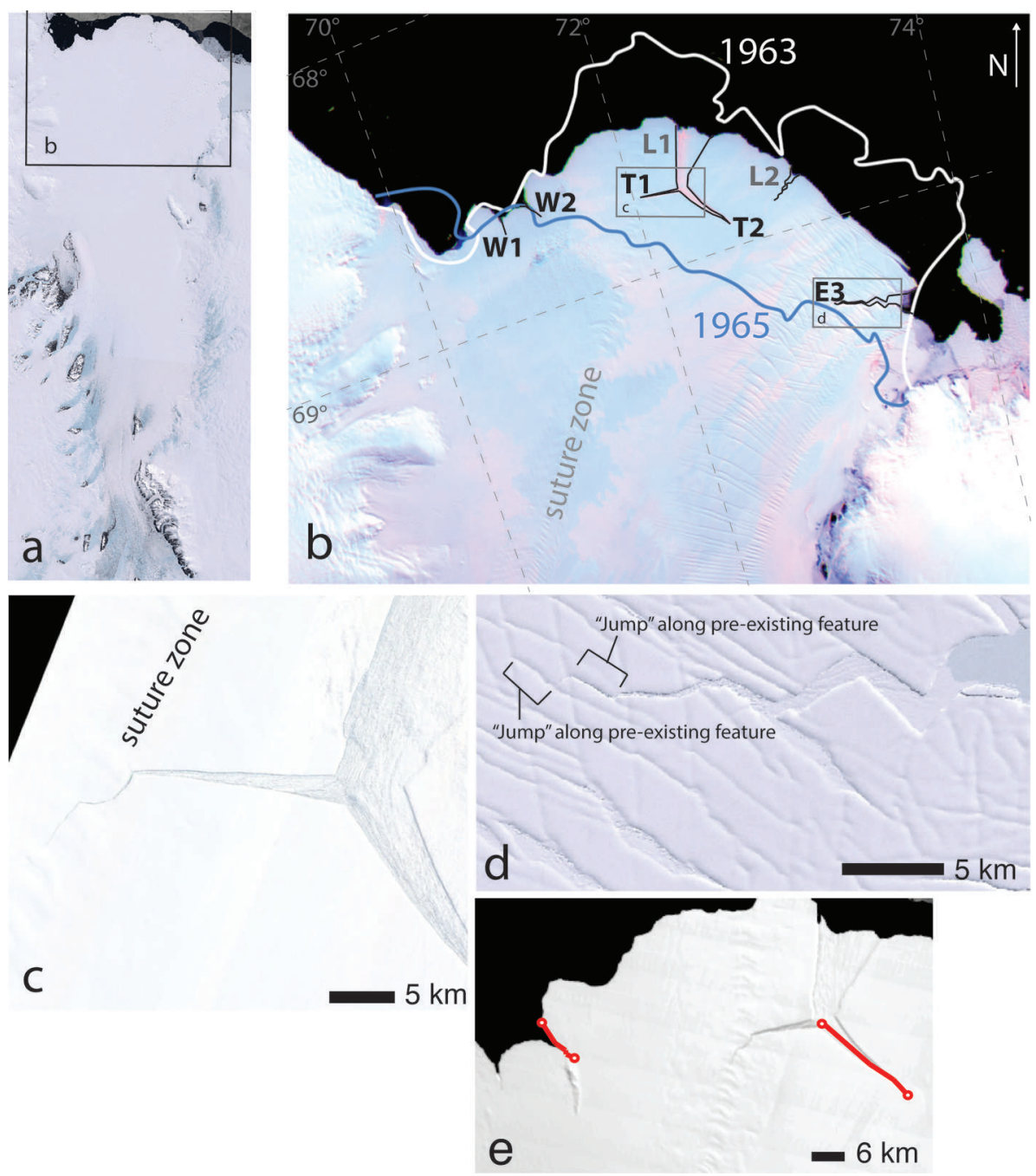

Fig. 1. False-color MISR (Multi-angle Imaging Spectroradiometer) images acquired on 7 January 2012 show (a) the full Amery Ice Shelf and (b) a zoomed-in view of the ice-shelf front relative to its front positions in 1963 (white) and 1965 (blue). These positions frame the extent of the ice shelf before and after its last major calving event in 1963/64. The five rifts monitored in this study are labeled in black. The central suture zone is labeled, and a surface fracture field is visible near the northeastern ice front. (c) A zoomed-in view of rift T1 acquired on 27 January 2012 , showing its changing propagation direction as it crosses a suture zone in the ice shelf. (d) A zoomed-in view of rift E3 acquired on 17 November 2002, showing its meandering path among the pre-existing fractures near the ice front. (e) Red curves denote beginning and end points for the rift measurement method. Shown here is a front-initiated rift (W2) and a rift initiated at a triple junction (T2).

Fricker and others (2005) and using satellite images with an average temporal resolution of 21 days from 2002 to 2014, instead of the 1-2 month observation scale of the study by Walker and others (2013). With this higher resolution and a dataset that spans a longer period, we seek to observe the temporal evolution of rift propagation behavior and evaluate the relationships between environmental forcings and dynamics of a multi-rift system.

\section{STUDY SITE}

The Amery Ice Shelf is supplied by the seaward flow of ice from three main tributary glaciers (Lambert, Mellor and Fisher) and has a surface area of $\sim 64000 \mathrm{~km}^{2}$ (Griggs and Bamber, 2011), making it the largest ice shelf in East Antarctica (e.g. Zhao and others, 2013). Its last major calving event occurred in late 1963/early 1964 (Budd, 1966), and in the intervening 50 years the ice shelf has steadily readvanced towards its pre-calved position (Fig. 1). During that time, six rifts have opened in the ice front (Fig. 1). Two longitudinal-to-flow rifts initiated at the ice front, opened $\sim 30 \mathrm{~km}$ apart, in the late 1980s (L1 and L2 in Fig. 1). L2 propagated until the early 1990s, when it reached a length of $\sim 15 \mathrm{~km}$ and then arrested. Around 1995, rift L1 bifurcated at its tip into two transverse rifts (T1 and T2), forming a triple junction, first observed in a 1997 satellite image (Fricker and others, 2002); this set of rifts makes up the 'Loose Tooth' rift system. Since then, two other rifts have initiated in the west part of the ice front, $\sim 10 \mathrm{~km}$ apart and propagated transverse-to-flow (W2 in the late 1990s, W1 in 2006). Rift E3 opened at the eastern part of the ice front before 1996; this rift propagates oblique-to-flow, and is visually distinct from the other rifts, as its propagation direction appears to be controlled by the pre-existing fractures in its vicinity (Fig. 1).

\section{DATA AND METHODOLOGY}

\section{Satellite imagery}

We collected available satellite imagery of the Amery Ice Shelf between January 2002 and January 2014 from the Multi-angle Imaging Spectroradiometer (MISR) instrument 


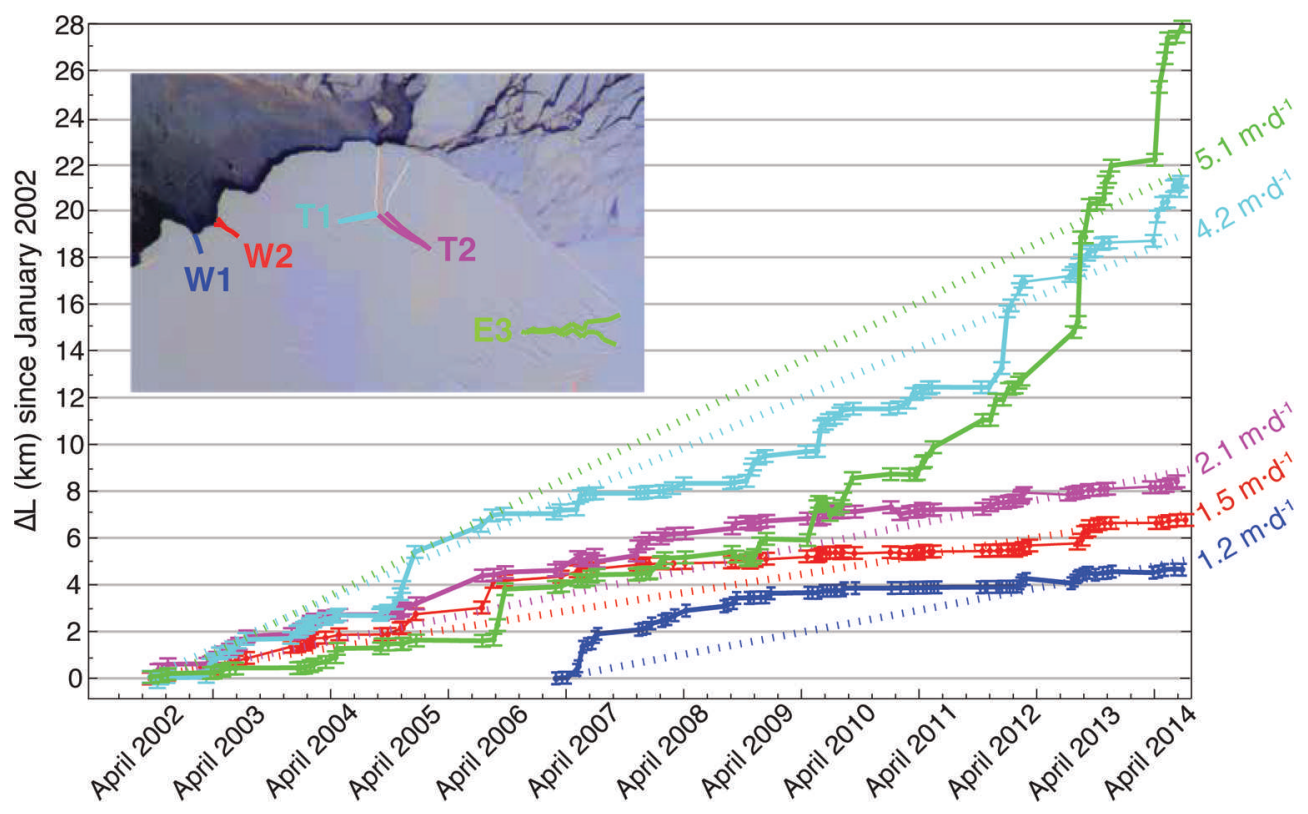

Fig. 2. Relative change in rift length for each of the five Amery Ice Shelf rifts monitored January 2002-January 2014. The rifts are color-coded as shown in the inset. Decadal averages are shown as dotted lines (with values shown on the right), computed by linear regression analysis.

on NASA's Terra spacecraft with a spatial resolution of $275 \mathrm{~m}$ and the Moderate Resolution Imaging Spectroradiometer (MODIS) instrument, on board both the Terra and Aqua spacecrafts, with a spatial resolution of $250 \mathrm{~m}$. We first determined suitable images from browse data, requiring that (1) the ice front was sunlit (September/October to March/April) and (2) the images were mostly free of cloud cover. For every suitable browse image, we downloaded the image file for further processing.

Visible imagery from the MODIS instrument was downloaded from the US National Snow and Ice Data Center (NSIDC; Scambos and others, 1996). Data from the MISR instrument were obtained from the NASA Langley Research Center Atmospheric Science Data Center (ASDC, 2013). The MISR instrument has nine digital cameras, configured so that one camera points toward nadir and the others provide successive forward and aft-ward views of the Earth's surface, each of which gathers image data in four spectral bands (blue, green, red, near-infrared; e.g. Diner and others, 2005). We acquired data files from the CA (blue), AN (green) and CF (red) camera bands and created false-color images using the publicly available MISRView software prior to image analysis. The use of MISR imagery improved our ability to view rift tips, because false-color, as a result of multiple camera look angles, acts as a proxy for reflectance variations from which we can infer changes in the surface texture (Fricker and others, 2005; Walker and others, 2013). In both the MODIS and MISR satellite imagery, we performed toning, brightening and contrast-stretching to enhance the visibility of the rifts and facilitate differentiation between the rift and background ice.

\section{Measuring rift lengths in satellite imagery}

We imported MISR and MODIS images into the publicly available United States Geological Survey's (USGS) QView program and used the length measurement capability to measure rift lengths in pixels. In each image we measured the lengths of the five rifts: three east-propagating (W1, W2 and T2; Fig. 1) and two west-propagating (T1 and E3; Fig. 1). To mitigate overestimation of rift lengths due to movement of the ice shelf, we measured lengths relative to points that we could consistently identify in each rift. For example, rifts T1 and $\mathrm{T} 2$ were measured from the center of the triple junction to the rift tip. This measurement is relative but consistent, and does not require geolocation information. We defined the 'rift tip' as the point at which a rift pixel was discernible, i.e. the point in the image where the rift occupied enough of a pixel to provide contrast against the background (Fig. 1). This is likely an underestimate of the true rift length, because near the tip the rift may be substantially narrower than a single pixel and the surface expression may be partially obscured by snow bridges. Although this may not represent the true rift tip, this method provides a systematic way to observe rift lengthening over time.

We calculated average annual and austral-summer and -winter propagation rates by fitting a straight line to the time series of rift lengths using least squares. The austral summer was defined as October to March; observations during austral winter were limited by lack of sunlight between late September and late March, and hence austral winter averages were limited to the sparse observations in early September and April.

\section{RESULTS}

All five of the rifts we monitored lengthened continuously during the observation period (Fig. 2). We define 'continuous' as the scenario in which the recurrence intervals between propagation events were comparable with or smaller than the repeat pass time of image acquisition, giving the appearance of continuous propagation in our image acquisition. Rifts W2, T1, T2 and E3 were observed from 2002 to 2014; rift W1 initiated in 2006 and was observed from then until 2014. Overall the three eastpropagating rifts (W1, W2 and T2) propagated slower than the two west-propagating rifts (E3 and T1). The westpropagating rifts are accelerating, while the trends of the east-propagating rifts indicate they are slowing down. 


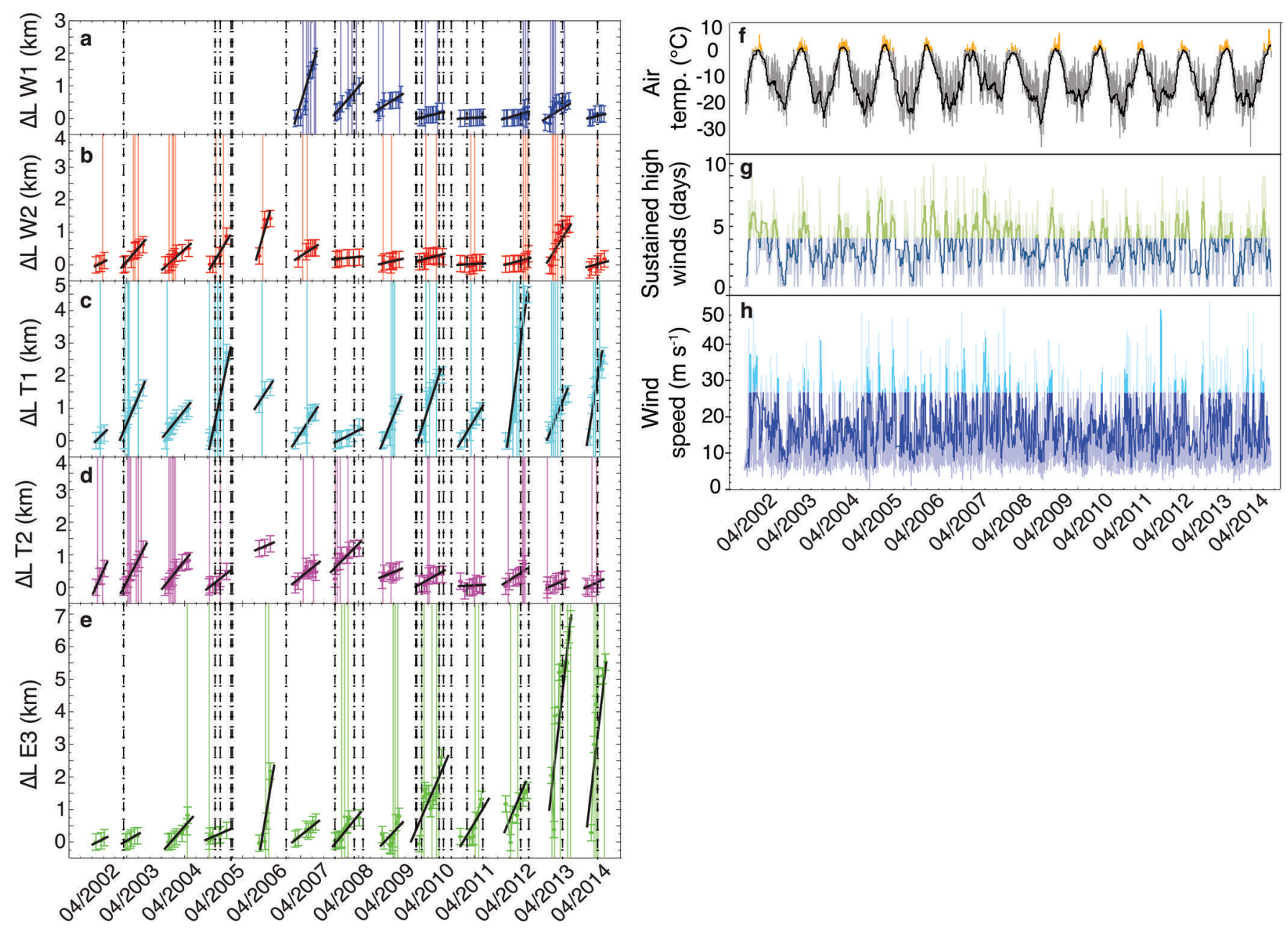

Fig. 3. Seasonal propagation (change in length, $\Delta L$ ), and air temperature and wind speed measured by automatic weather stations at Mawson and Davis stations. (a-e) Rift length change relative to the beginning of each season and annual average rates (black) for each rift. Vertical lines signify 'large propagation events'. Dotted lines show tsunami run-up in the Amery Ice Shelf region. (f) Daily-averaged air temperature in black is overlaid by orange highlights that denote temperatures $>0{ }^{\circ} \mathrm{C}$ (smoothed signal highlighted). (g) Number of days spent at 'high' winds (blue) overlaid by green highlights that show 'sustained high winds'. (h) Daily wind speeds (dark blue) overlaid by light blue highlights showing winds above two standard deviations of mean (smoothed signal highlighted).

Rift W1 had the lowest long-term rate $\left(1.2 \mathrm{~m} \mathrm{~d}^{-1}\right)$, while rift E3 had the highest rate $\left(5.1 \mathrm{md}^{-1}\right.$; Fig. 2). We also observed large interannual variability of rift propagation rates (Fig. 3). We conducted a linear regression analysis for each summer season (case A, Table 1) and, using $t$-tests (e.g. Wilks, 2011), found that, for each rift, slopes for the summers differ from each other between different years at the $95 \%$ confidence interval. For most years, the change in length of the rift between the end of each austral summer and the beginning of the following summer was near zero, confirming previous findings that rift propagation primarily occurs during the summer, with only a little propagation during the winter (Fricker and others, 2005). This was confirmed using a regression analysis on the dataset to determine the difference between 'average summer' rates (case B, Table 1 ) and a straight-line fit to all data (case $C$, Table 1). The average winter growth in all rifts was $<250 \mathrm{~m}$ (one pixel); however, there were two exceptions to this pattern: (1) during the winter of 2005 three rifts (W2, T1 and T2) exhibited higher than average winter propagation $(\sim 250,1100$ and $1200 \mathrm{~m}$, respectively) and (2) during the winter of 2011, rift E3 lengthened by $2.1 \mathrm{~km}$ (Fig. 3). As noted by Walker and others (2013), the timing of the 2005 winter events corresponds to the arrival of tsunamis in the region. The large jump in length of rift E3 over the winter of 2011 coincided with the rift intersecting a pre-existing fracture.

The time series for each rift show several intermittent 'large propagation events', which we define as individual propagation events with rates greater than the interquartile range of the data (Fig. 3). During these events, the rift significantly lengthened over a short period. Within each rift, these events tended to dominate the average rift propagation rates (cases D, E, F in Table 1). We observed a total of 142 large rift propagation events across the five rifts. The number of large propagation events that occurred each season varied interannually; however, overall they were distributed approximately evenly between austral spring, midsummer and autumn. Our observed distribution of large propagation events (for all rifts) was not distinguishable from a uniform distribution, and hence their occurrence does not appear to be related to the changing conditions between spring, midsummer and autumn. Overall, the rifts experienced similar numbers of large propagation events during the 12 year observation period (ranging from 23 for W1 to 34 for T1), but their occurrence varied over the years, and there was little synchronicity of large events between the rifts for any given year (Fig. 4). There were three instances in which the east-propagating rifts all 
Table 1. Propagation rates $\left(\mathrm{m} \mathrm{d}^{-1}\right)$ derived from measured rift length time series and $95 \%$ confidence intervals $(\mathrm{Cl})$ using three regression analyses. Case A: individual season slopes; case B: 'average summer' slopes; case C: full 12 year time series slopes; case D: individual season slopes with large events removed; case E: 'average summer' slopes with large events removed; case F: full 12 year series slopes with large events removed

\begin{tabular}{|c|c|c|c|c|c|c|c|c|c|c|c|}
\hline \multirow[b]{2}{*}{ Case } & \multirow[b]{2}{*}{ Season } & \multicolumn{2}{|c|}{ W1 } & \multicolumn{2}{|c|}{ W2 } & \multicolumn{2}{|c|}{$\mathrm{T} 1$} & \multicolumn{2}{|c|}{$\mathrm{T} 2$} & \multicolumn{2}{|c|}{ E3 } \\
\hline & & Rate & $\mathrm{Cl}$ & Rate & $\mathrm{Cl}$ & Rate & $\mathrm{Cl}$ & Rate & $\mathrm{Cl}$ & Rate & $\mathrm{Cl}$ \\
\hline \multirow[t]{11}{*}{ A } & $2001 / 02$ & & & 1.8 & 0.2 & 3.6 & 0.4 & 7.9 & 0.8 & 1.8 & 0.1 \\
\hline & $2002 / 03$ & & & 4.0 & 1.1 & 8.3 & 2.4 & 6.8 & 2.0 & 2.1 & 0.4 \\
\hline & $2003 / 04$ & & & 2.8 & 0.8 & 4.4 & 1.3 & 4.3 & 1.3 & 4.0 & 1.1 \\
\hline & $2004 / 05$ & & & 5.9 & 1.0 & 16.7 & 4.1 & 2.8 & 0.7 & 1.6 & 0.3 \\
\hline & $2006 / 07$ & 12.2 & 3.6 & 2.3 & 0.6 & 5.5 & 1.5 & 2.9 & 0.8 & 2.9 & 0.7 \\
\hline & $2007 / 08$ & 4.1 & 1.2 & 0.3 & 0.1 & 1.8 & 0.5 & 3.6 & 1.1 & 4.4 & 1.3 \\
\hline & 2008/09 & 2.3 & 0.6 & 0.8 & 0.2 & 8.8 & 2.2 & 1.5 & 0.4 & 3.9 & 1.0 \\
\hline & $2009 / 10$ & 1.0 & 0.3 & 0.9 & 0.3 & 11.0 & 3.3 & 2.0 & 0.6 & 8.3 & 2.5 \\
\hline & $2010 / 11$ & 0.2 & 0.1 & 0.3 & 0.1 & 5.8 & 1.7 & 0.2 & 0.1 & 5.9 & 1.5 \\
\hline & $2011 / 12$ & 1.2 & 0.4 & 1.2 & 0.4 & 28.9 & 8.6 & 3.2 & 1.0 & 10.2 & 3.0 \\
\hline & $2012 / 13$ & 2.0 & 0.7 & 5.7 & 1.8 & 8.9 & 2.8 & 1.4 & 0.5 & 38.9 & 11.9 \\
\hline B & & 2.3 & 0.9 & 2.9 & 1.1 & 9.3 & 3.5 & 3.6 & 1.4 & 10.5 & 3.9 \\
\hline C & & 1.3 & 0.5 & 1.4 & 0.6 & 4.6 & 1.7 & 1.8 & 0.7 & 5.2 & 1.9 \\
\hline \multirow[t]{13}{*}{$\mathrm{D}$} & $2001 / 02$ & & & 1.1 & 0.02 & 3.4 & 0.1 & 7.9 & 0.1 & 1.8 & 0.02 \\
\hline & $2002 / 03$ & & & 3.9 & 0.7 & 8.3 & 1.5 & 6.6 & 1.4 & 2.1 & 0.4 \\
\hline & $2003 / 04$ & & & 2.7 & 0.5 & 4.4 & 1.3 & 4.3 & 1.2 & 2.9 & 0.7 \\
\hline & $2004 / 05$ & & & 3.3 & 0.1 & 5.5 & 0.1 & 2.8 & 0.5 & 1.6 & 0.3 \\
\hline & $2005 / 06$ & & & 12.0 & 0.2 & 5.4 & 0.1 & 1.5 & 0.02 & 1.0 & 0.02 \\
\hline & $2006 / 07$ & 10.7 & 1.1 & 2.3 & 0.4 & 5.5 & 0.1 & 2.6 & 1.0 & 2.8 & 0.6 \\
\hline & $2007 / 08$ & 3.9 & 0.7 & 0.3 & 0.1 & 1.8 & 0.5 & 3.6 & 0.9 & 3.6 & 0.8 \\
\hline & $2008 / 09$ & 2.3 & 0.6 & 0.8 & 0.2 & 8.0 & 0.8 & 1.5 & 0.4 & 2.9 & 0.5 \\
\hline & $2009 / 10$ & 0.9 & 0.3 & 0.9 & 0.3 & 11.2 & 2.8 & 2.0 & 0.6 & 8.3 & 1.6 \\
\hline & $2010 / 11$ & 0.2 & 0.05 & 0.3 & 0.1 & 5.9 & 1.6 & 0.2 & 0.04 & 0.1 & 0.01 \\
\hline & $2011 / 12$ & 1.1 & 0.4 & 0.7 & 0.2 & 27.1 & 2.7 & 2.5 & 0.7 & 10.2 & 2.7 \\
\hline & $2012 / 13$ & 1.1 & 0.3 & 5.7 & 1.5 & 8.9 & 2.3 & 1.4 & 0.5 & 38.9 & 11.9 \\
\hline & $2013 / 14$ & 1.1 & 0.3 & 1.6 & 0.4 & 18.4 & 2.2 & 2.2 & 0.6 & 41.4 & 1.0 \\
\hline
\end{tabular}

exhibited a large propagation event simultaneously, and eight instances in which the two west-propagating rifts had large propagation events on the same day. Occasionally two or three rifts experienced a large propagation event on the same day, but there were none in which all five rifts had large propagation events within the same observational period (repeat-pass time interval).

\section{DISCUSSION}

Our results confirm the main finding of Fricker and others (2005) that was based on two rifts in the Amery Ice Shelf: rift propagation rates for all five rifts in our study have a strong seasonal component. However, the pattern of rift propagation we observe is far more complex than initially recognized. For instance, we see large interannual variability in rift propagation rates; also, the differing behavior of rifts based on propagation direction (i.e. deceleration of east-propagating rifts vs acceleration of west-propagating rifts). Much of the variability we observed is related to occasional large bursts of propagation. Previous authors have suggested a link between rift propagation rates and external meteorological and climate conditions. To investigate if these large bursts of propagation were triggered by unusual environmental conditions we conducted linear regression analyses to compare the time series of rift lengths with four proxies for environmental variables: air temperature, ocean swell, wind speed and unusually high ocean waves (tsunamis). Additionally, previous studies have found that internal glaciological stress and structural elements within or below the ice have been cited as plausible drivers of rift propagation (e.g. Bassis and others, 2008; Holland and others, 2009; Jansen and others, 2010, 2013; Heeszel and others, 2014; Kulessa and others, 2014). We assessed the observable structural elements within the Amery Ice Shelf to determine whether the observed large bursts of propagation coincided with changing ice-shelf properties.

\section{Investigating the link between rift propagation and environmental variables}

To determine whether there is a link between our derived rift propagation rates and environmental conditions, we acquired several climate datasets with which to compare our time series: (1) air temperature; (2) wind speed and (3) sea-ice concentration. We obtained (1) and (2) from the Australian Antarctic Data Center (AADC; Barnes-Keogahn, 2014), recorded at automatic weather stations at Davis and Mawson stations during the period 2002-14. The Amery Ice Shelf ice front is located between these stations, farther north than Davis and farther south than Mawson. We obtained (3) from monthly Nimbus-7 scanning multichannel microwave radiometer (SMMR) and US Defense 


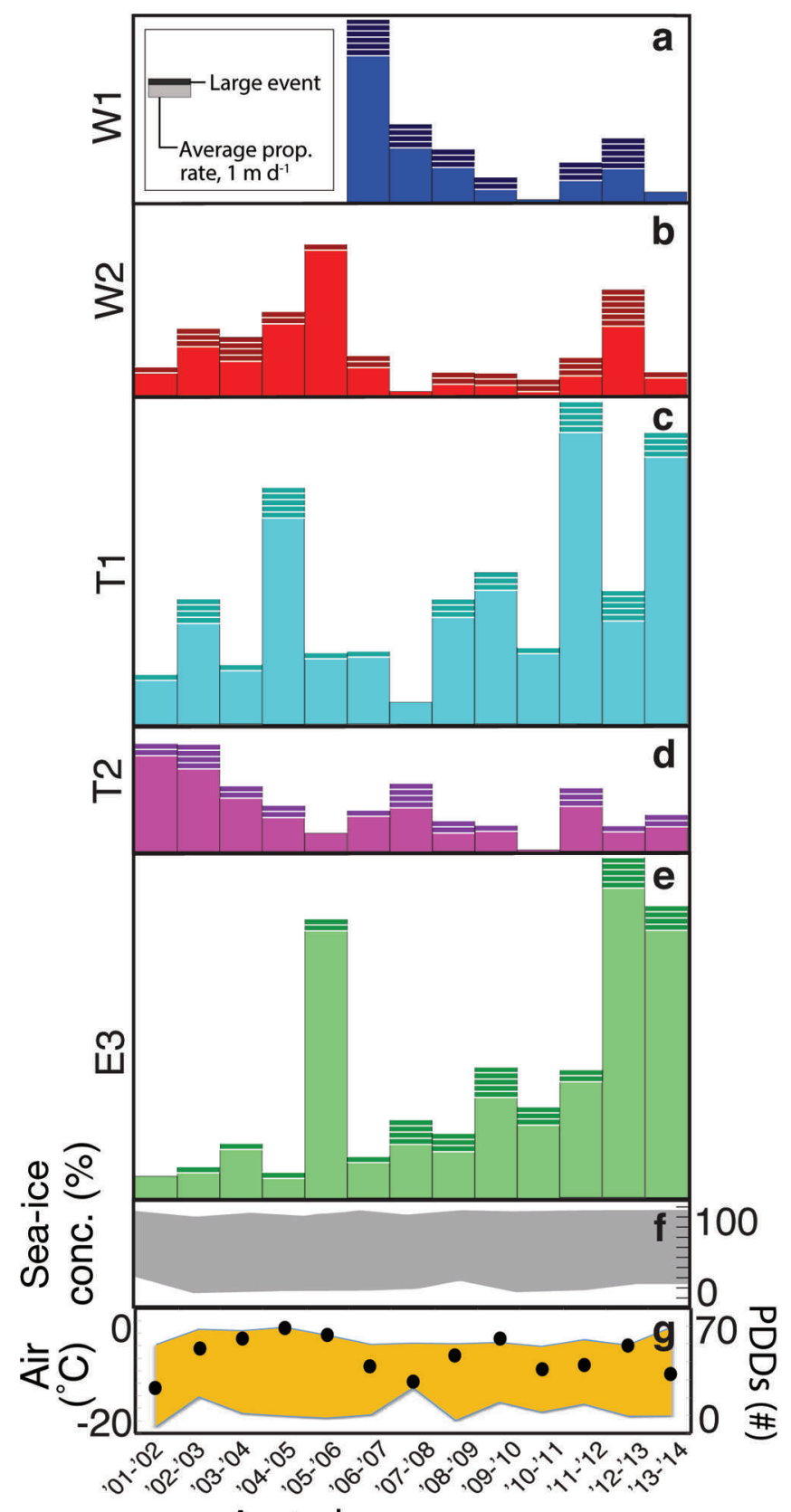

Austral summer season

Fig. 4. Seasonal averages of rift propagation, sea-ice concentration and air temperature. (a-e) Average rift propagation rate $\left(\mathrm{m} \mathrm{d}^{-1}\right)$ for each rift and each season. Darker top blocks show number of large propagation events in each rift for each year. (f) Gray region shows range of annual sea-ice extent in front of Amery Ice Shelf. (g) Orange region shows range of average temperatures. Black dots show number of positive degree-days (PDDs).

Meteorological Satellite Program (DMSP) Special Sensor Microwave/Imager (SSM/I-SSMIS) passive microwave data of sea-ice concentration, archived at the NSIDC (Cavalieri and others, 1996).

\section{Air temperature}

We estimated positive degree-days (PDDs) using the mean degree-hours method (e.g. Day, 2006), where we determined the total sum of hourly $(j)$ averaged temperatures, $T_{j}$, per day above our base temperature, $T_{\mathrm{b}}$, of $0^{\circ} \mathrm{C}$ : $D_{\mathrm{d}}=\sum_{j=1}^{24}\left(T_{j}-T_{\mathrm{b}}\right)_{\left(\left(T_{j}-T_{\mathrm{b}}\right)>0\right)} / 24$. Daily degree-days, $D_{\mathrm{d}}$, were then summed over each season. Investigating the relationship between PDDs and rift propagation events more closely, we compared our calculated PDDs with the occurrence of rift propagation events (Fig. 5). We did not observe a statistically significant correlation between the number of PDDs and timing of rift events. Days with zero propagation (and rift events that did not qualify as large) correlated with high PDD periods just as often as (if not more often than) large propagation events (Fig. 5). This suggests that large rift events are not related to rising temperatures during a season. Instead, large propagation events occurred approximately uniformly over a season, even before any positive temperatures were recorded. Using a linear regression analysis, the correlation between $>0^{\circ} \mathrm{C}$ temperatures and the timing of rift propagation events was not calculated to be statistically significant at the $95 \%$ confidence interval.

\section{Wind speeds}

We looked for a correlation between rift activity and 'anomalous' wind speeds, i.e. speeds two standard deviations or more above the average wind speed from 2002 to 2014. None of the large propagation events were found to coincide with anomalous winds. Using linear regression analysis, we found that that the correlation between wind speeds and rift propagation was not statistically significant, with coefficients staying close to zero $(0.16$ for W1, 0.11 for W2, 0.03 for T1, 0.04 for T2 and -0.5 for E3). This supports Bassis and others (2005), who observed no instantaneous correlation between days with high winds and rift propagation in rift T2. However, Bassis and others (2005) did observe that two out of three large 'bursts' in rift T2 occurred following periods of sustained strong winds. We considered sustained strong winds to be when at least four days were above average within the week prior to the rifting event. We observed that 75 of the 142 large propagation events, approximately evenly across all rifts, took place after periods of sustained strong winds, which might suggest that sustained winds may have a small influence on the timing of propagation events. However, the correlation may not be causal, in that sustained periods of high winds might also generate significant ocean swell. We consider this hypothesis next.

\section{Sea-ice concentration}

Ocean swell has been hypothesized to mechanically trigger ice-shelf rift propagation, but ocean swell can be dampened by the presence of sea ice in front of the shelf (e.g. SchulzStellenfleth and Lehner, 2002; Bassis and others, 2008; Bromirski and others, 2010). Both rift propagation and sea ice have strong seasonal signals. We first removed the seasonal signal from the sea-ice dataset to directly compare the variability of the sea-ice concentration and rifting rates. If sea-ice concentration controlled the propagation of rifts, we would expect that years with higher (lower) than average concentration would correlate with lower (higher) annual propagation rates in the ice shelf. While there are some years with more extreme variation (e.g. winter 2004 and summer 2002/03), for the most part sea ice oscillated from $25 \%$ to $85 \%$ concentration (Fig. 4). The correlation coefficient between the time series of rift lengths with seaice concentration was not statistically significant, the only exception being rift E3, which is the widest rift in our study. The satellite imagery shows that it is filled with ice melange for most of the year (Fig. 1d) and is visibly filled with sea ice for most of the year. It is possible that sea ice around or 

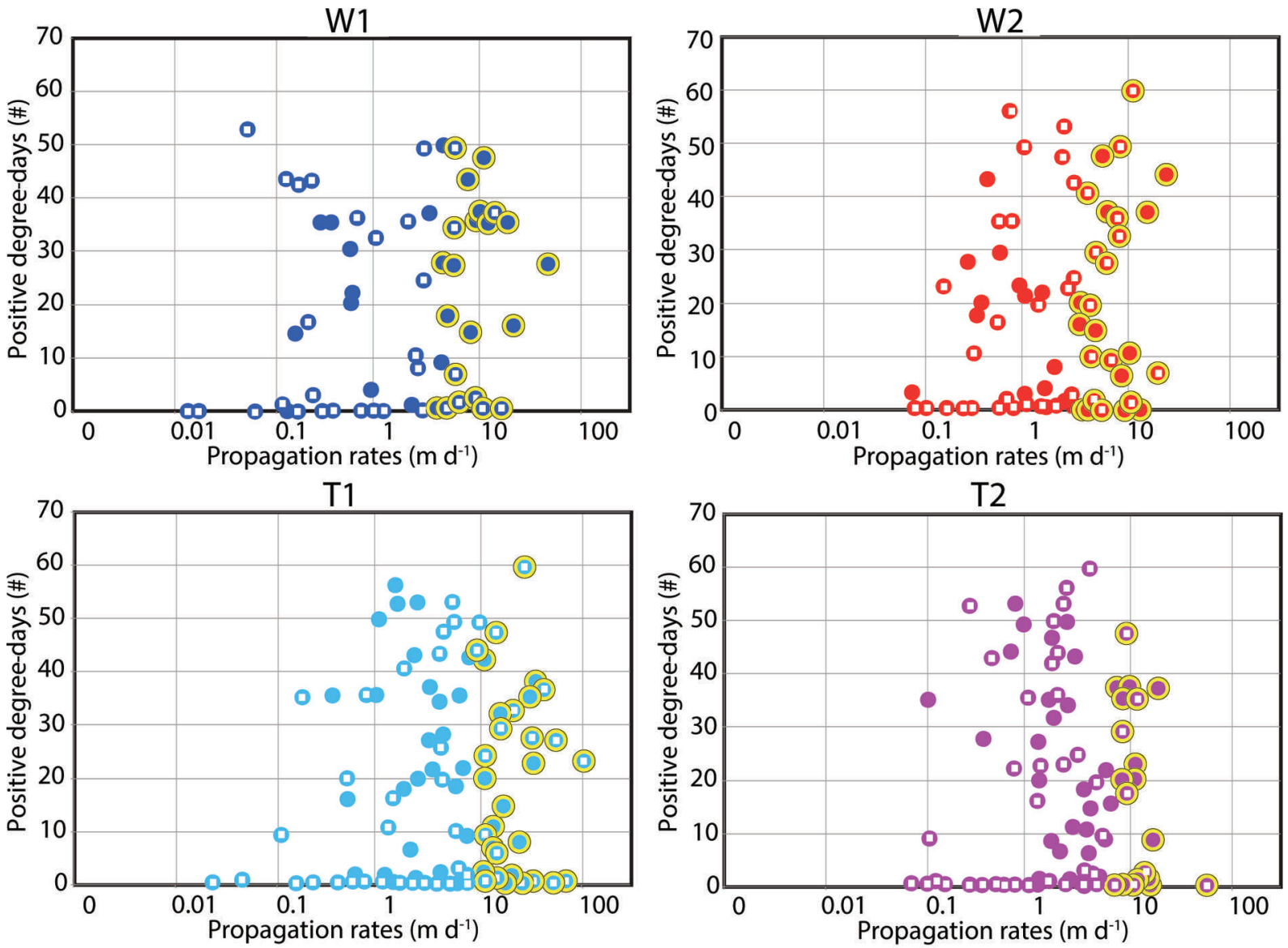

E3

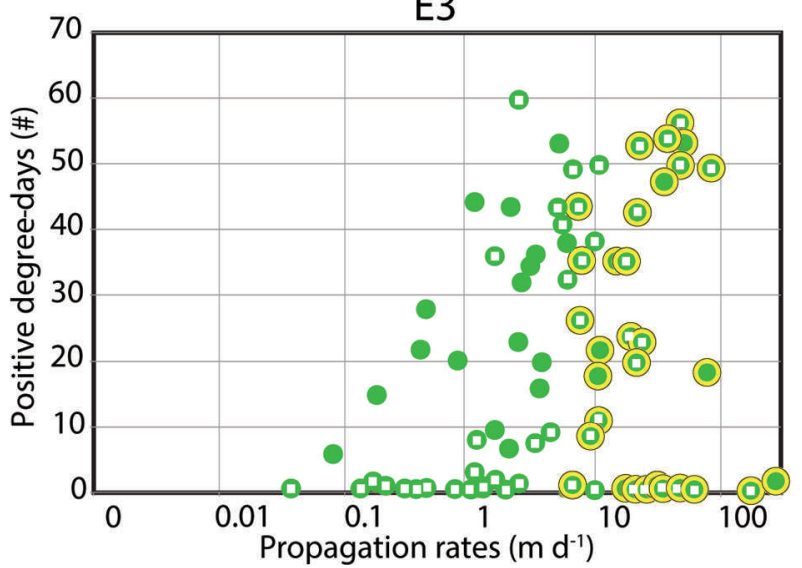

Fig. 5. Large propagation events vs PDDs on the Amery Ice Shelf, 2002-14. Each panel shows rift propagation rates measured between 2002 and 2014 for each rift (color-coded as Fig. 2 inset map), plotted against the number of PDDs. Yellow-circled dots signify those events that were classified as large propagation events for each rift. White squares signify those events preceded by at least 4 days of sustained high winds.

within the rift buffers the ice shelf from other influences and helps to stabilize the rift (Hulbe and others, 2010). Borstad and others (2013), for example, suggested that thicker melange within a rift could be associated with less-damaged rifts. We note, however, that we have no direct observations of longer-period infra-gravity waves (e.g. Bromirski and Stephen, 2012) and cannot rule out a mechanical interaction with these longer-period waves.

\section{Arrival of tsunamis}

Previously, Brunt and others (2011) and Walker and others (2013) have documented the effect of tsunamis on frontinitiated ice-shelf rifts, demonstrating that tsunami arrivals around the Antarctic continent correlated with large rift propagation events or iceberg calving events throughout the decade (2002-12). The effect appears to be most pronounced for the Amery Ice Shelf rifts. Of the 24 tsunamis that caused run-up in the Amery Ice Shelf region between 2002 and 2014 (data from the Historical Tsunami Database maintained by the US National Oceanic and Atmospheric Administration (NOAA) National Geophysical Data Center), we detected 15 instances in which one or more of the rifts propagated between documented wave arrival and the next available clear observation, limited to being within 1 month (Fig. 3). Furthermore, the abnormal winter propagation event we observed in winter 2005 is coincident with the predicted impact of two tsunamis associated with Indonesian tsunamigenic earthquakes, suggesting that these events may have been triggered by tsunami impact. Using a chi-squared test, we found that the correlation between the arrival of the 
tsunami and the timing of large bursts of propagation is statistically significant at the $90 \%$ confidence level.

\section{Investigating the role of structural variability in rift propagation}

Despite the strong seasonal signal present for all five rifts, we found that of the four environmental proxies for which we compared data (temperature, sea ice, winds, tsunamis), only one correlation was statistically significant (tsunamis). The lack of widespread synchronized simultaneous propagation of the rifts makes it doubtful that any large-scale environmental variable is the primary driver of rift propagation for the Amery Ice Shelf, although we cannot discount environmental influences modifying the precise timing of propagation events. However, considerations of ice structure may better explain the variability of the rift propagation patterns that we observed.

\section{Correlation between closely spaced rifts}

While there are many environmental influences that could drive rift propagation and we cannot monitor them all, environmental forcings from the atmosphere and ocean typically have length scales of tens to hundreds of kilometers. If these forcings are driving rift propagation, we expect that this should appear as coherent propagation between nearby rifts. To investigate whether or not this is true, we calculated the Pearson correlation coefficient between rift propagation rates for each pair of rifts. The only pair with a statistically significant correlation at the 95\% confidence interval over the entire observation period was the pairing of rifts $\mathrm{W} 1$ and $\mathrm{W} 2$, with a correlation coefficient of 0.3 . Rifts $\mathrm{T} 1$ and $\mathrm{E} 3$, the west-propagating rifts, showed a positive correlation of 0.2 , statistically significant only at the $90 \%$ confidence level. The correlation in propagation between rift $\mathrm{W} 1$ and rift $\mathrm{W} 2$ might be explained by considering that rift $W 1$ initiated $\sim 10 \mathrm{~km}$ from rift $W 2$, and the closely spaced rifts respond to the same stressors. Both $\mathrm{T} 1$ and $\mathrm{E} 3$ are west-propagating rifts, suggesting a possible directional synchronization.

\section{Alternative explanations for rift propagation variability} Despite the apparent lack of correlation between rift activity and large-scale environmental parameters, with the exception of tsunamis, the clear seasonal signal we observe leads us to believe that a component of environmental forcing is responsible for some of the observed variability in rift propagation. While the variability in annual propagation rate does not correlate with any of the parameters we examined, it may be that a combination of environmental changes and/or effects during the summer months in the ice (possibly in both the ice-shelf ice and sea ice) or surrounding ocean allows for an increase in propagation. For example, while air temperature increases during the summer, moorings in the sub-ice-shelf cavity indicate a seasonal variability in the oceanography beneath the ice shelf, which may imply there is a spatially variable seasonal signal in the basal melt and refreezing rates under the ice shelf (Herraiz-Borreguero and others, 2013). This may be particularly relevant because structural heterogeneity within the shelf may also influence rift propagation. We noticed that the surface expression of basal and surface crevasses visible in satellite imagery, like those at the eastern front of the Amery Ice Shelf, creates zones of previously fractured ice and we hypothesize this system plays some role in controlling the propagation of the rift (Heeszel and others, 2014). There may also be prominent basal crevasses present, that are not clearly expressed on the surface of the ice shelf, that contribute to the heterogeneous pattern of rift propagation. Anecdotally at least, we see some evidence to support this hypothesis. For example, rift T1 changed propagation direction several times upon entering a suture zone between two ice streams (Fig. 1). It is possible that bands of marine ice (not identifiable in satellite imagery) are playing similar roles in controlling the propagation of other rifts (e.g. Holland and others, 2009; Kulessa and others, 2014).

Without evidence to support environmental triggers for rift propagation, we hypothesize that the enhanced rift propagation of the Amery Ice Shelf, relative to other ice shelves (Walker and others, 2013), is related to a combination of structural heterogeneity and its current position close to its most recent extended position prior to calving in 1963/64. Intriguingly, the active rifts on the Amery Ice Shelf are also front-initiated, a trait that sets them apart from most of the rifts detected and monitored in other ice shelves (Walker and others, 2013). This front initiation likely occurs on Amery Ice Shelf because it was a confined ice shelf that has spread out horizontally over the ocean as it exited its embayment into Prydz Bay. While Zhao and others (2013) observed that the rate of advance of the Amery Ice Shelf front had decreased during the period 2004-12, we did not see that reflected in overall rift propagation rate over the same period, which suggests that ice velocity does not solely control rift propagation rates. While the shelf front has decelerated overall as it has exited its embayment, lateral stretching may maintain high local strain rates and these high strain rates lead to continued rifting, which was observed for only a few other rifts around Antarctica (Walker and others, 2013). As the Amery Ice Shelf approaches its previously most-extended position, it will be important to continue monitoring the propagation activity across all five rifts to enable further analysis of whether or not the ice shelf might be poised for a large calving event, and how changes in or maintenance of current rift activity might signal that process.

\section{CONCLUSIONS}

We have generated time series of rift lengths for five rifts at the front of the Amery Ice Shelf using MISR and MODIS satellite imagery for the period 2002-14. While all five rifts lengthened over the observation period, the three eastpropagating rifts slowed significantly after 2010, while the two west-propagating rifts continued to propagate at high rates, and have even accelerated. The average propagation rates for the period differed between rifts. Within each rift, propagation rates varied annually and exhibited a seasonal pattern, with higher rates occurring during the austral summer and almost no propagation during austral winter. We observed that nearby rifts exhibited linked behavior, with a statistically significant correlation between the timing of rift events. We also considered the occurrence of large propagation events, which dominated the seasonal averages. The number of large propagation events per rift and per season varied, and their timing was not consistent across all rifts. This observation suggests that all rifts were not responding to the same stressor; if, however, they were responding to the same stressor, the observation suggests rifts do not respond equally or synchronously to the same trigger. 
We examined the possibility that propagation rates might be correlated with external environmental factors, as they clearly follow a seasonal signal. However, comparison of our rift dataset with atmospheric temperature, wind speed and sea-ice concentration does not suggest that any of these phenomena are direct triggers of rift propagation. As such, the cause of the seasonal signal remains a mystery.

The five rifts in this study are unusual in that they initiated and extend from the shelf front, rather than initiating upstream, like most other rifts observed on Antarctic ice shelves (e.g. Walker and others, 2013). The fact that structural heterogeneity, internal glaciological stress due to shelf geometry, possible sustained winds and intermittent tectonic events (by way of tsunamis) contribute to the propagation of rifts and that the rifts exhibit interactive behavior suggests that these parameters must be accounted for in modeling rift propagation in ice shelves. By continuing to observe the rifts, in the future it may be possible to connect rifting activity levels to the imminence or likelihood of large calving events.

\section{ACKNOWLEDGEMENTS}

This work was supported by NASA grant NNX10AB216G, NSF CAREER-NSF-ANT 114085, and NSF grant EAGERNSF-ARC 1064535.

\section{REFERENCES}

ASDC (Atmospheric Science Data Center) (2013) MISR Level $1 B 2$ Ellipsoid Data-MIB2E. NASA Langley Research Center, Hampton, VA htpps://cosweb.larc.nasa.gov/project/misr/misr_table

Barnes-Keogahn I (2014) AASM Antarctic climate data collected by Australian Agencies. Bureau of Meteorology, Australian Antarctic Data Centre, Hobart http://data.aad.gov.au/aade/metadata/ metadata_redirect.cfm?md=/AMD/AU/Antractic_Meteorology

Bassis JN, Coleman R, Fricker HA and Minster JB (2005) Episodic propagation of a rift on the Amery Ice Shelf, East Antarctica. Geophys. Res. Lett., 32(6), L06502 (doi: 10.1029/ 2004GL022048)

Bassis JN and 7 others (2007) Seismicity and deformation associated with ice-shelf rift propagation. J. Glaciol., 53(183), 523-536 (doi: 10.3189/002214307784409207)

Bassis JN, Fricker HA, Coleman R and Minster J-B (2008) An investigation into the forces that drive ice-shelf rift propagation on the Amery Ice Shelf, East Antarctica. J. Glaciol., 54(184), 17-27 (doi: 10.3189/002214308784409116)

Benn DI, Warren CW and Mottram RH (2007) Calving processes and the dynamics of calving glaciers. Earth-Sci. Rev., 82(3-4), 143-179 (doi: 10.1016/j.earscirev.2007.02.002)

Borstad CP, Rignot E, Mouginot J and Schodlok MP (2013) Creep deformation and buttressing capacity of damaged ice shelves: theory and application to Larsen C ice shelf. Cryosphere, 7(6), 1931-1947 (doi: 10.5194/tc-7-1931-2013)

Bromirski PD and Stephen RA (2012) Response of the Ross Ice Shelf, Antarctica, to ocean gravity-wave forcing. Ann. Glaciol., 53(60 Pt 2), 163-172 (doi: 10.3189/2012AoG60A058)

Bromirski PD, Sergienko OV and MacAyeal DR (2010) Transoceanic infragravity waves impacting Antarctic ice shelves. Geophys. Res. Lett., 37(2), L02502 (doi: 10.1029/2009GL041488)

Brunt KM, Okal EA and MacAyeal DR (2011) Antarctic ice-shelf calving triggered by the Honshu (Japan) earthquake and tsunami, March 2011. J. Glaciol., 57(205), 785-788 (doi: 10.3189/002214311798043681)

Budd W (1966) The dynamics of the Amery Ice Shelf. J. Glaciol., 6(45), 335-358
Cavalieri DJ, Parkinson CL, Gloersen P and Zwally HJ (1996) Sea ice concentrations from Nimbus-7 SMMR and DMSP SSM/ I-SSMIS passive microwave data (updated 2012). NASA Distributed Active Archive Center, National Snow and Ice Data Center, Boulder, CO http://nsidc.org/data/nsidc-0051.html

Day T (2006) Degree days: theory and application. (CIBSE Technical Memorandum TM41) Chartered Institution of Building Services Engineers, London

Diner DJ and 14 others (2005) The value of multiangle measurements for retrieving structurally and radiatively consistent properties of clouds, aerosols, and surfaces. Remote Sens. Environ., 97(4), 495-518 (doi: 10.1016/j.rse.2005.06.006)

Fricker HA, Young NW, Allison I and Coleman R (2002) Iceberg calving from the Amery Ice Shelf, East Antarctica. Ann. Glaciol., 34, 241-246 (doi: 10.3189/172756402781817581)

Fricker HA, Young NW, Coleman R, Bassis JN and Minster JB (2005) Multi-year monitoring of rift propagation on the Amery Ice Shelf, East Antarctica. Geophys. Res. Lett., 32(2), L02502 (doi: 10.1029/2004GL021036)

Griggs JA and Bamber JL (2011) Antarctic ice-shelf thickness from satellite radar altimetry. J. Glaciol., 57(203), 485-498 (doi: 10.3189/002214311796905659)

Heeszel DS, Fricker HA, Bassis JN, O'Neel S and Walter F (2014) Seismicity within a propagating ice shelf rift: the relationship between icequake locations and ice shelf structure. J. Geophys. Res., 119(F4), 731-744 (doi: 10.1002/2013JF002849)

Herraiz-Borreguero L, Allison I, Craven M, Nicholls KW and Rosenberg MA (2013) Ice shelf/ocean interactions under the Amery Ice Shelf: seasonal variability and its effect on marine ice formation. J. Geophys. Res., 118(12), 7117-7131 (doi: 10.1002/ 2013JC009158)

Holland PR, Corr HFJ, Vaughan DG, Jenkins A and Skvarca P (2009) Marine ice in Larsen Ice Shelf. Geophys. Res. Lett., 36(11), L11604 (doi: 10.1029/2009GL038162)

Hulbe CL, Ledoux C and Cruikshank K (2010) Propagation of long fractures in the Ronne Ice Shelf, Antarctica, investigated using a numerical model of fracture propagation. J. Glaciol., 56(197), 459-472 (doi: 10.3189/002214310792447743)

Humbert A and Steinhage D (2011) The evolution of the western rift area of the Fimbul Ice Shelf, Antarctica. Cryosphere, 5(4), 931-944 (doi: 10.5194/tcd-5-1089-2011)

Jacobs SS, MacAyeal DR and Ardai JL Jr (1986) The recent advance of the Ross Ice Shelf, Antarctica. J. Glaciol., 32(112), 464-474

Jansen D, Kulessa B, Sammonds PR, Luckman A, King EC and Glasser NF (2010) Present stability of the Larsen C ice shelf, Antarctic Peninsula. J. Glaciol., 56(198), 593-600 (doi: 10.3189/ $002214310793146223)$

Jansen D, Luckman A, Kulessa B, Holland PR and King EC (2013) Marine ice formation in a suture zone on the Larsen $C$ Ice Shelf and its influence on ice shelf dynamics. J. Geophys. Res., 118(3), 1628-1640 (doi: 10.1002/jgrf.20120)

Joughin I and MacAyeal DR (2005) Calving of large tabular icebergs from ice shelf rift systems. Geophys. Res. Lett., 32(2), L02501 (doi: 10.1029/2004GL020978)

Kulessa B, Jansen D, Luckman A, King EC and Sammonds PR (2014) Marine ice regulates the future stability of a large Antarctic ice shelf. Nature Commun., 5, 3707 (doi: 10.1038/ ncomms4707)

Larour E, Rignot E and Aubry D (2004) Modelling of rift propagation on Ronne Ice Shelf, Antarctica, and sensitivity to climate change. Geophys. Res. Lett., 31(16), L16404 (doi: 10.1029/ 2004GL020077)

Lazzara MA, Jezek KC, Scambos TA, MacAyeal DR and Van der Veen CJ (1999) On the recent calving of icebergs from the Ross Ice Shelf. Polar Geogr., 23(3), 201-212 (doi: 10.1080/ 10889370802175937)

MacAyeal DR and 13 others (2006) Transoceanic wave propagation links iceberg calving margins of Antarctica with storms in tropics and Northern Hemisphere. Geophys. Res. Lett., 33(17), L17502 (doi: 10.1029/2006GL027235) 
MacAyeal DR, Okal EA, Aster RC and Bassis JN (2009) Seismic observations of glaciogenic ocean waves (micro-tsunamis) on icebergs and ice shelves. J. Glaciol., 55(190), 193-206 (doi: 10.3189/002214309788608679)

MacGregor J, Catania GA, Markowski MS and Andrews AG (2012) Widespread rifting and retreat of ice-shelf margins in the eastern Amundsen Sea Embayment between 1972 and 2011. J. Glaciol., 58(209), 458-466 (doi: 10.3189/2012JoG11J262)

Rignot E, Jacobs S, Mouginot J and Scheuchl B (2013) Ice-shelf melting around Antarctica. Science, 341(6143), 266-270 (doi: 10.1126/science.1235798)

Scambos T, Bohlander J and Raup B (1996) Images of Antarctic ice shelves [2002-present]. National Snow and Ice Data Center, Boulder, CO. Digital media: http://nsidc.org/data/iceshelves_ images/index_modis.html
Schulz-Stellenfleth J and Lehner S (2002) Spaceborne synthetic aperture radar observations of ocean waves traveling into sea ice. J. Geophys. Res., 107(C8) (doi: 10.1029/2001JC000837)

Sergienko OV (2010) Elastic response of floating glacier ice to impact of long-period ocean waves. J. Geophys. Res., 115(F4), F04028 (doi: 10.1029/2010JF001721)

Walker CC, Bassis JN, Fricker HA and Czerwinski RJ (2013) Structural and environmental controls on Antarctic ice shelf rift propagation inferred from satellite monitoring. J. Geophys. Res., 118(4), 2354-2364 (doi: 10.1002/2013jf002742)

Wilks DS (2011) Statistical methods in the atmospheric sciences, 3rd edn. Academic Press, Oxford

Zhao C and 11 others (2013) Monitoring the Amery Ice Shelf front during 2004-2012 using ENVISAT ASAR data. Adv. Polar Sci., 24(2), 133-137

MS received 12 August 2014 and accepted in revised form 5 December 2014 